\title{
ANALISIS KEPUTUSAN ETIS DI SEKRETARIAT DEWAN PERWAKILAN RAKYAT DAERAH PROVINSI BENGKULU
}

\author{
Oleh: \\ YUSUARSONO \\ Dosen Prodi Administrasi Publik Fakultas Ilmu-Ilmu Sosial UNIVED Bengkulu
}

\begin{abstract}
This study aimed to determine the Employee Ethical Decision Legislative Council Secretariat Bengkulu province. The research method was qualitative. Informants in this study were all secretariat employees of the Regional Representatives Council of Bengkulu province. Data was collected by using purposive sampling technique through interviews. Data analysis was performed through three (3) stages: reduction, display, and inference and verification. The results showed that ethical decision on the Secretariat of Bengkulu Province Council seen from benefits criteria, some decisions are tied to the interest of Council's member. Seen from rights criteria, the Council members didn't focus on the rights and interests of all organization or instances and employees. If it's seen from fairness criteria, the fairness doesn't applied well for the lazy and diligent employees receive the same honorarium. In addition the appointment of PPTK (Official Technical Users Activity) only employees who are close to the leaders who were appointed. However, because it's the leader's decision, all employees must comply. Likewise with seniority, works often given to senior employees without involving the new ones, so that the new employees are learning slowly.
\end{abstract}

Keywords: Ethical Decision Criteria Benefits, Council, Employee

\section{PENDAHULUAN}

Berdasarkan data Sekretariat Dewan Perwakilan Rakyat Daerah Provinsi Bengkulu dalam pelaksanaan kegiatan daftar honor kegiatan PPTK, terlihat nama-nama yang ditugaskan di setiap komisi, tidak berhak mendapatkan honor dari kegiatan PPTK karena keputusan tersebut dikeluarkan langsung oleh Pengguna Anggaran (PA).

Survei awal pada Sekretariat Dewan Perwakilan Rakyat Daerah Provinsi Bengkulu dalam pengambilan-pengambilan keputusan yang dilakukan di tempat kerja seringkali tidak sesuai dengan apa yang mereka harapkan, keputusan yang ambil di tempat kerja membedakan kinerja pegawai, keputusan yang ambil di tempat kerja tidak membedakan senioritas pegawai, pegawai bagian tidak melakukan diskusi atau tidak melibatkan pegawai yang lainnnya, dan pada bagian persidangan dilihat dari kriteria berfokus pada hak menunjukkan atasan minta masukan dari bawahannya apabila telah terjadi permasalahan atau konflik di tempat kerja, serta dilihat dari kriteria berfokus pada keadilan, pada bagian humas, pembagian tugas tidak adil dikarenakan tugas diberikan kepada orang yang dianggap mampu saja, sehingga dalam melaksanakan tugas tidak ada pemerataan diantara pegawai.

Berdasarkan uraian dan permasalahan di atas, maka dalam penelitian ini perlu diangkat penelitian tentang permasalahan keputusan etis kriteria manfaat, berfokus pada hak, dan fokus pada keadilan Di 
sekretariat Dewan Perwakilan Rakyat Daerah Provinsi Bengkulu.

Untuk mengetahui keputusan etis kriteria manfaat, berfokus pada hak, dan fokus pada keadilan di sekretariat Dewan Perwakilan Rakyat Daerah Provinsi Bengkulu?

\section{TINJAUAN PUSTAKA \\ Pengambilan Keputusan}

Pengambilan keputusan adalah proses yang disengaja dalam membuat pilihan diantara satu atau beberapa alternatif dengan tujuan mencapai sesuatu yang diinginkan. Keputusan muncul sebagai respon terhadap masalah atau peluang. Masalah (problem) adalah penyimpangan dari situasi yang ada saat ini dengan situasi yang diinginkan (Robbins. 2006:254).

\section{Keputusan Etis}

Keputusan etis adalah keputusan tentang apa yang benar dan apa yang salah. Karenanya, ia adalah keputusan yang sering sulit dan rumit. Sementara sikap dan keputusan etis mau tidak mau harus dilakukan, dan tidak bisa dihindari Karena ia bagian hidup manusia. Pengambilan keputusan yang etis merupakan suatu kriteria yang penting dalam pengambilan keputusan organisasional. Bagian dari pembuatan keputusan etis adalah alasan moral (Suwarto, 1998:33).

Tiga kriteria keputusan etis yaitu: (Suwarto, 1998:47).

1. Kriteria manfaat, di mana keputusankeputusan diambil semata-mata atas dasar hasil atau konsekuensi dengan tujuan utilitarianisme yaitu keputusan-keputusan diambil sedemikian rupa sehingga memberikan kebaikan terbesar dari jumlah terbesar:

2. Kriteria berfokus pada hak, kriteria ini mempersilahkan individu-individu untuk mengambil keputusan yang konsisten dengan kebebasan dan keistimewaan mendasar seperti dikemukakan dalam dokumen-dokumen. Tekanan pada hak ini berarti menghormati dan melindungi hakhak dasar dari para individu, seperti misalnya hak keleluasan pribadi (privacy), kebebasab berbicara, dan perlindungan hak.

3. Kriteria berfokus pada keadilan, pada kriteria ini mensyaratkan individuindividu untuk mengenakan dan memperkuat aturan-aturan secara adil dan tidak berat sebelah sehingga ada pembagian manfaat dan biaya yang pantas. Kriteria ini membenarkan pembayaran upah yang sama kepada orang-orang untuk suatu pekerjaan tertentu, tanpa membedakan kinerja, dan penggunaan senioritas sebagai penentuan primer dalam mengambil keputusan pemberhentian massal.

\section{Kerangka Analisis}

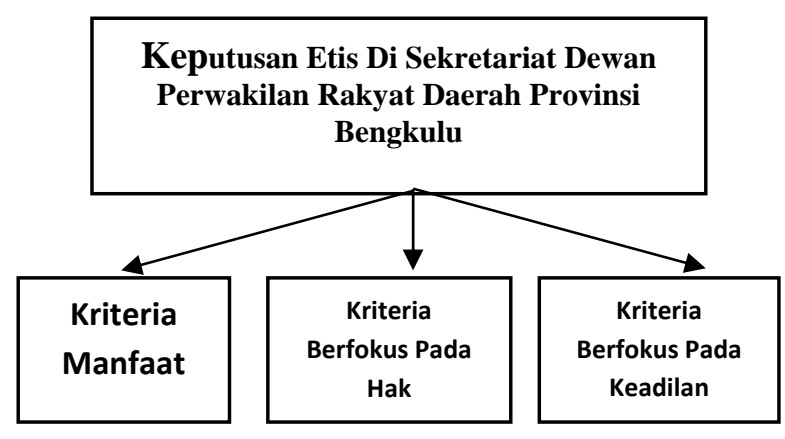

\section{METODOLOGI PENELITIAN}

Jenis penelitian yang digunakan dalam penelitian ini mengarah pada penggunaan metode penelitian deskriptif kualitatif. Metode kualitatif adalah metode penelitian yang digunakan untuk penelitian pada objek alamiah dimana peneliti adalah instrument kunci (Sugiono 2008:41).

Keputusan Etis adalah keputusan pimpinaan yang diambil atau diputuskan dalam Sekretariat Dewan Perwakilan Rakyat Daerah Provinsi Bengkulu dalam hal pemberian tugas pada pegawai, pembagian bidang pekerjaan, dan pembagian honor dalam pelaksanaaan kegiatan yang dilihat dari aspek: 
1. Kriteria manfaat, di mana keputusankeputusan diambil semata-mata atas dasar hasil atau konsekuensi dengan tujuan utilitarianisme (yang bermanfaat) bagi sekretariat Dewan Perwakilan Rakyat Daerah (DPRD) Provinsi Bengkulu yaitu:

a. Keputusan-keputusan sekretariat Dewan Perwakilan Rakyat Daerah (DPRD) Provinsi Bengkulu diambil untuk memberikan kebaikan bagi sekretariat.

b. Keputusan-keputusan sekretariat Dewan Perwakilan Rakyat Daerah (DPRD) Provinsi Bengkulu diambil memberikan manfaat yang terbesar bagi berjalannya kegiatan sekretariat.

2. Kriteria berfokus pada hak, kriteria ini mempersilahkan pimpinan sekretariat Dewan Perwakilan Rakyat Daerah (DPRD) Provinsi Bengkulu untuk mengambil keputusan yang konsisten dengan kebebasan dan keistimewaan mendasar seperti:

a. Sekretariat Dewan Perwakilan Rakyat Daerah (DPRD) Provinsi Bengkulu dalam membuat keputusan memperhatikan dan menghormati hakhak dasar dari para pegawai sekretariat dalam melaksanakan pekerjaannnya.

b. Sekretariat Dewan Perwakilan Rakyat Daerah (DPRD) Provinsi Bengkulu melindungi hak-hak dasar dari para pegawai dalam melaksanakan pekerjaannya.

3. Kriteria fokus pada keadilan, pada kriteria ini mensyaratkan sekretariat Dewan Perwakilan Rakyat Daerah (DPRD) Provinsi Bengkulu untuk mengenakan dan memperkuat aturan-aturan secara adil dan tidak berat sebelah sehingga ada pembagian manfaat dan biaya yang pantas.

a. Sekretariat Dewan Perwakilan Rakyat Daerah (DPRD) Provinsi Bengkulu memberikan pembayaran upah yang sama kepada semua pegawai b. Sekretariat Dewan Perwakilan Rakyat Daerah (DPRD) Provinsi Bengkulu tanpa membedakan kinerja pegawai

c. Sekretariat Dewan Perwakilan Rakyat Daerah (DPRD) Provinsi Bengkulu menghargai dan penggunaan senioritas Informan dalam penelitian ini seluruh pegawai sekretariat Dewan Perwakilan Rakyat Daerah Provinsi Bengkulu sebanyak 8 (delapan) orang yang diambil dari masingmasing Bagian, dengan rincian Bagian Umum 2 orang, Bagian Persidangan 2 orang, Bagian Hubungan Masyarakat (Humas) 2 orang, dan Bagian Keuangan 2 orang. Dimana masing masing Bagian diambil 1 orang Kepala Bagian dan 1 orang staf. Teknik pengambilan sampel dalam ini menggunakan porposive sampling, yaitu pengambilan responden berdasarkan pertimbangan peneliti.

Analisis data yang digunakan dalam penelitian ini adalah analisis kualitatif. Analisis data penelitian ini merupakan interpretasi data yang berbentuk kualitatif dengan tahapan pengumpulan, reduksi, interpretasi, penyajian dan penarikan kesimpulan yang merupakan langkah akhir penelitian yang diambil melalui wawancara dilapangan. Analisa data yang dilakukan melalui wawancara dengan cara berulangulang dan berkesinambungan antara pengumpulan dan analisis data, baik selama pengumpulan data di lapangan maupun sesudah data terkumpul. Analisa data dilakukan melalui 3 (tiga) tahap yaitu: (Sugiono, 2008: 44).

1. Reduksi data yaitu menyederhanakan data yang banyak dengan membuat abstraksi sehingga diketahui secara jelas intisari dan tema pokoknya sesuai dengan fokus masalah yang diteliti.

2. Display data yaitu dengan mensistematiskan pokok-pokok informasi dengan tema dan polanya yang nampak akan ditarik suatu kesimpulan sehingga data informasi yang dikumpulkan akan bermakna, mengingat data yang terkumpul semakin banyak, sehingga 
dapat memberikan gambaran dan dapat disajikan secara sistematis dengan memperhatikan kronologinya dan ditonjolkan pokok-pokoknya sehingga dapat dikuasai secara jelas.

3. Penyimpulan dan verifikasi yaitu merangkum data dan informasi dalam display, sehingga bermakna karena kesimpulan awal biasanya relatif, maka agar kesimpulan semakin mantap, perlu dilakukan verifikasi selama penelitian berlangsung. Penyimpulan dan verifikasi merupakan pengambilan intisari dari sajian data yang telah terorganisasi dalam bentuk pernyataan kalimat singkat dan bermakna.

Teknik Analisis Data penelitian kualitatif yaitu setelah rangkaian data terkumpul, selanjutnya dilakukan analisis data dengan prosedur dan teknis pengolahan berikut: (Salim dan Syahrum, 2010: 132).

1. Melakukan pemilahan dan penyusunan klasifikasi data

2. Melakukan penyunting data dan pemberian kode data untuk membangun kinerja analisis data

3. Melakukan konfirmasi data yang memerlukan verifikasi data dan pendalaman data

4. Melakukan analisis data sesuai dengan konstruksi pembahasan hasil penelitian.

Menurut Salim dan Syahrum (2010:

132) pengolahan data kualitatif dilakukan dalam beberapa tahapan yaitu:

1. Tahap pertama pengolahan data dimulai dari penelitian pendahuluan hingga tersusunnya usulan penelitian.

2. Tahap kedua, pengolahan data yang lebih mendalam dilakukan dengan cara mengolah hasil kegiatan wawancara dan pengumpulan berbagai informasi lapangan di lokasi penelitian.

3. Tahap ketiga, setelah itu dilakukan pemeriksaan keabsahan data hasil wawancara dengan sejumlah nara sumber yang dijadikan informan penelitian serta membandingkan data tersebut dengan berbagai informasi yang terkait.
Keabsahan data dimaksud untuk memperoleh tingkat kepercayaan yang berkaitan dengan seberapa jauh kebenaran hasil penelitian, mengungkapkan dan memperjelas data dengan fakta-fakta aktual di lapangan. Dalam penelitian kualitatif keabsahan data lebih bersifat sejalan seiring dengan proses penelitian itu berlangsung. Keabsahan data kualitatif harus dilakukan sejak awal pengambilan data, yaitu sejak melakukan reduksi data, display data dan penarikan kesimpulan atau verifikasi. Pada tahap ini, pengolahan data dianggap optimal apabila data yang diperoleh sudah layak dianggap lengkap dan dapat merepresentasikan masalah yang dijadikan obyek penelitian.

4. Tahap akhir adalah analisis data dalam rangka menjawab pertanyaan-pertanyaan penelitian yang dilakukan dengan pendekatan analisis triangulasi.

Teknik Keabsahan Data dalam penelitian ini menggunakan Triangulasi Sumber dan Triangulasi Teknik (Sugiono, 2008:273). Teknik ini digunakan untuk melihat tingkat keakuratan dari temuan hasil penelitian yang dilakukan. Dalam penelitian ini dilakukan teknik triangulasi sumber yaitu wawancara dengan beberapa sumber.

Triangulasi Sumber untuk menguji kredebilitas data yang dilakukan dengan cara mengecek data yang telah diperoleh dari bebarapa sumber. Dalam hal ini ini peneliti melakukan pengumpulan data melalui wawancara mendalam (in depth interview).

\section{Triangulasi Teknik}

Triangulasi Teknik untuk menguji kredibilitas data dilakukan dengan cara mengecek data kepada sumber yang sama dengan teknik yang berbeda. Dalam hal ini peneliti melakukan pengumpulan data melalui wawancara mendalam (in dept interview), melihat dokumentasi dan observasi. 


\section{HASIL PENELITIAN DAN PEMBAHASAN}

Hasil penelitian tentang keputusan etis pada sekretariat Dewan Perwakilan Rakyat Daerah Provinsi Bengkulu belum etis, hal ini dikarenakan keputusan yang diambil masih memiliki kepentingankepentingan seseorang atau sekelompok orang. Selain itu keputusan yang diambil belum bersifat adil, hal ini dikarenakan dalam pemberian kagiatan atau pembagian tugas, ditunjuk orang yang dekat dengan atasan dan memiliki hubungan kekeluragaan.

Hasil penelitian tentang keputusan etis dilihat dari kriteria manfaat, berfokus pada hak, dan fokus pada keadilan pada pegawai sekretariat Dewan Perwakilan Rakyat Daerah Provinsi Bengkulu dijabarakan di bawah ini:

\section{Keputusan Etis Kriteria Manfaat}

Keputusan etis pada Sekretariat Dewan Perwakilan Rakyat Daerah Provinsi Bengkulu dilihat dari kriteria manfaat masih terdapat keputusan yang memiliki syarat kepentingan seperti kepentingan anggota dewan dan pemerintah, sehingga keputusan tersebut kurang memperhatian azas manfaat bagi instansi Sekretariat Dewan Perwakilan Rakyat Daerah Provinsi Bengkulu.

Keputusan etis pada Sekretariat Dewan Perwakilan Rakyat Daerah Provinsi Bengkulu dilihat dari kriteria manfaat masih terdapat keputusan yang memiliki syarat kepentingan seperti kepentingan anggota dewan dan pemerintah, sehingga keputusan tersebut kurang memperhatikan azas manfaat bagi instansi Sekretariat Dewan Perwakilan Rakyat Daerah Provinsi Bengkulu.

Sementara itu hasil observasi peneliti keputusan yang diambil bukan memberikan kriteria manfaat, melainkan keputusan yang diambil tersebut membuat kecemburuan antara pegawai yang satu dengan yang lainnya, sehingga menyebabkan pegawai malas dan kurang termotivasi dalam melaksanakan tugas. Selain itu kadangkala keputusan yang diambil di sekretaris dewan tersebut mendahulukan pegawai yang mempunyai hubungan kedekatan dengan anggota dewan yaitu masih terdapat hubungan kekeluargaan (Nepotisme).

\section{Keputusan Etis Berfokus Pada Hak}

Keputusan etis pada Sekretariat Dewan Perwakilan Rakyat Daerah Provinsi Bengkulu belum memperhatikan hak hak atau kepentingan organisasi atau instansi maupun pegawai, sehingga tidak memperhatikan kepentingan pegawai dan keputusan tanpa melibatkan bawahan atau pegawai.

Keputusan etis pada Sekretariat Dewan Perwakilan Rakyat Daerah Provinsi Bengkulu belum memperhatikan hak hak atau kepentingan organisasi atau instansi maupun pegawai, sehingga tidak memperhatikan kepentingan pegawai dan keputusan tanpa melibatkan bawahan atau pegawai.

Keputusan etis pada Sekretariat Dewan Perwakilan Rakyat Daerah Provinsi Bengkulu dilihat dari kriteria berfokus pada hak belum memperhatikan hak hak atau kepentingan organisasi atau instansi maupun pegawai, sehingga tidak memperhatikan kepentingannya dan keputusan tanpa melibatkan bawahan atau pegawai. Selain itu pegawai jarang diminta masukan atau saran terhadap keputusan yang diambil.

Hasil observasi penelitia setiap kali pengambilan keputusan di dalam rapat, seringkali pendapat atau saran yang diberikan oleh staf, tidak digubris, walaupun di gubris, hanya sebatas mendengarkan saja dan saran itu tidak pernah diterima. Padahal pegawai/staf juga mempunyai hak dan kepentingan di tempat mereka bekerja.

\section{Keputusan Etis Kriteria Fokus Pada Keadilan}

Keputusan etis pada Sekretariat Dewan Perwakilan Rakyat Daerah Provinsi Bengkulu dilihat dari kriteria berfokus pada keadilan belum bersifat adil karena antara pegawai yang malas dan pegawai yang rajin 
mendapatkan honor yang sama, bahkan dibagian tertentu staf di komisi tidak mendapatkan honor kegiatan, dikarenakan sudah di komisi, sehingga tidak boleh mendapatkan honor kegiatan di PPTK, seperti pemberian honor tidak dibedakan antara pegawai yang rajin dengan yang malas. Selain itu juga penunjukkan PPTK (pejabat Pengguna Teknis Kegiatan) hanya pegawai yang dekat dengan pimpinan dan tidak berbagi tugas dengan pegawai yang lain. Namun karena itu sudah keputusan pimpinan, maka semua pegawai harus mematuhinya.

Keputusan etis pada Sekretariat Dewan Perwakilan Rakyat Daerah Provinsi Bengkulu dilihat dari kriteria berfokus pada keadilan belum bersifat adil karena antara pegawai yang malas dan pegawai yang rajin sama, bahkan dibagian tertentu staf di komisi tidak mendapatkan honor kegiatan, dikarenakan sudah di komisi sehingga tidak boleh mendapatkan honor kegiatan di PPTK, seperti pemberian honor tidak dibedakan antara pegawai yang rajin dengan yang malas. Selain itu juga penunjukkan PPTK (pejabat Pengguna Teknis Kegiatan) hanya pegawai yang dekat dengan pimpinan dan tidak berbagi tugas dengan pegawai yang lain. Namun karena itu sudah keputusan pimpinan, maka semua pegawai harus mematuhinya. Begitu juga dengan senioritas, seringkali pekerjaan diberikan kepada pegawai yang senior tanpa melibatkan pegawai yang baru, sehingga pegawai yang baru lambat memahami pekerjaan yang dilakukan.

Hal ini sesuai dengan hasil observasi peneliti terlihat pada pagi hari pegawai diruang kerja hanya duduk dan bercerita sesama rekan kerja, padahal pekerjaan masih banyak yang belum selesai. Selain itu juga didukung dari temuan dokumentasi surat tugas, dimana dalam surat tugas tersebut, sangat terlihat sekali hanya pegawai yang itu saja yang diberi tugas. Selain itu ditemukan juga daftar pemberian honorarium, dimana pegawai yang rajin dan yang malas, diberi honor yang sama, sehingga menyebakan terjadinya kecemburuan social antara pegawai yang rajin.

\section{Pembahasan}

Keputusan etis pada Sekretariat Dewan Perwakilan Rakyat Daerah Provinsi Bengkulu selama ini masih belum etis dikarenakan keputusan dalam hal penunjukkan atau pemberian Surat Perintah Tugas dalam satu bagian hanya diberikan dengan orang orang tertentu saja dan Surat Perintah Tugas itu tidak sesuai dengan bidang tugasnya. pembagian tugas dan pekerjaan dan pembagian honor kegiatan terhadap pegawai yang ada belum sesuai dan belum etis, sehingga keputusan yang di ambil menyebabkan terjadinya kecemburuan sosial antara sesama pegawai.

Keputusan etis pada Sekretariat Dewan Perwakilan Rakyat Daerah Provinsi Bengkulu kriteria manfaat masih terdapat keputusan yang memiliki syarat kepentingan seperti kepentingan anggota dewan dan pemerintah, sehingga keputusan tersebut kurang memperhatian azas manfaat bagi instansi Sekretariat Dewan Perwakilan Rakyat Daerah Provinsi Bengkulu.

Sementara itu Keputusan etis pada Sekretariat Dewan Perwakilan Rakyat Daerah Provinsi Bengkulu dilihat dari kriteria berfokus pada hak belum memperhatikan hak hak atau kepentingan organisasi atau instansi maupun pegawai, sehingga tidak memperhatikan kepentingan pegawai dan keputusan tanpa melibatkan bawahan atau pegawai. Selain itu pegawai jarang diminta masukan atau saran terhadap keputusan yang diambil

Sementara itu Keputusan etis pada Sekretariat Dewan Perwakilan Rakyat Daerah Provinsi Bengkulu dilihat dari kriteria berfokus pada keadilan belum bersifat adil karena antara pegawai yang malas dan pegawai yang rajin sama, bahkan dibagian tertentu staf di komisi tidak mendapatkan honor kegiatan, dikarenakan sudah di komisi sehingga tidak boleh 
mendapatkan honor kegiatan di PPTK, seperti pemberian honor tidak dibedakan antara pegawai yang rajin dengan yang malas. Selain itu juga penunjukkan PPTK (pejabat Pengguna Teknis Kegiatan) hanya pegawai yang dekat dengan pimpinan dan tidak berbagi tugas dengan pegawai yang lain. Namun karena itu sudah keputusan pimpinan, maka semua pegawai harus mematu hinya. Begitu juga dengan senioritas, seringkali pekerjaan diberikan kepada pegawai yang senior tanpa melibatkan pegawai yang baru, sehingga pegawai yang baru lambat memahami pekerjaan yang dilakukan.

Dampak dari keputusan yang diambil tidak etis, menyebabkan pegawai yang tadinya rajin menjadi malas dan kadangkala ada pegawai yang tidak masuk kerja tanpa memberikan keterangan. Selain itu menyebabkan kurang hormonisnya hubungan antara pegawai yang rajin dengan yang malas, sehingga kadangkala menyebabkan pekerjaan yang dilakukan lambat dalam penyelesaianya.

Hasil temuan penelitian di atas menunjukkan bahwa keputusan di Sekretariat Dewan Perwakilan Rakyat Daerah Provinsi Bengkulu tidak memperhatikan kriteria manfaat, berfokus pada hak, dan tidak berfokus pada keadilan. Oleh karena itu hendaknya Sekretaris Dewan Perwakilan Rakyat Daerah Provinsi Bengkulu dalam lebih memperhatikan setiap keputusan yang diambil, sehingga keputusan yang diambil itu benar dan etis dan tidak menyebakan kecemburuan sosial antara sesama pegawai.

Selain itu pemberian keputusan dalam masing masing bagian dapat diberikan sesuai tugas pegawai masing masing, jangan hanya diberikan kepada pegawai tertentu saja yang tidak sesuai dengan tugasnya karenakan ada kepentingan ada ada kedekatan secara emosional.

\section{PENUTUP}

\section{Kesimpulan}

1. Keputusan etis pada Sekretariat Dewan Perwakilan Rakyat Daerah Provinsi Bengkulu dilihat dari kriteria manfaat masih terdapat keputusan yang memiliki syarat kepentingan seperti kepentingan anggota Dewan dan pemerintah, sehingga keputusan tersebut kurang memperhatian azas manfaat bagi instansi Sekretariat Dewan Perwakilan Rakyat Daerah Provinsi Bengkulu.

2. Keputusan etis pada Sekretariat Dewan Perwakilan Rakyat Daerah Provinsi Bengkulu dilihat dari kriteria berfokus pada hak belum memperhatikan hak hak atau kepentingan organisasi atau instans maupun pegawai, sehingga tidak memperhatikan kepentingan pegawai dan keputusan tanpa melibatkan bawahan atau pegawai. Selain itu pegawai jarang diminta masukan atau saran terhadap keputusan yang diambil.

3. Keputusan etis pada Sekretariat Dewan Perwakilan Rakyat Daerah Provinsi Bengkulu dilihat dari kriteria berfokus pada keadilan belum bersifat adil karena antara pegawai yang malas dan pegawai yang rajin sama, bahkan dibagian tertentu staf di komisi tidak mendapatkan honor kegiatan, dikarenakan sudah di komisi sehingga tidak boleh mendapatkan honor kegiatan di PPTK, seperti pemberian honor tidak dibedakan antara pegawai yang rajin dengan yang malas. Selain itu juga penunjukkan PPTK (pejabat Pengguna Teknis Kegiatan) hanya pegawai yang dekat dengan pimpinan dan tidak berbagi tugas dengan pegawai yang lain. Namun karena itu sudah keputusan pimpinan, maka semua pegawai harus mematuhinya. Begitu juga dengan senioritas, seringkali pekerjaan diberikan kepada pegawai yang senior tanpa melibatkan pegawai yang baru, sehingga pegawai yang baru lambat memahami pekerjaan yang dilakukan. 


\section{Saran}

1. Kepada Sekretaris Dewan Perwakilan Rakyat Daerah Provinsi Bengkulu diharapkan dalam mengambil keputusan hendaknya dapat etis dengan memperhatikan azas menfaat yang mengutamakan kepentingan dan kebaikan instansi dan pegawai.

2. Kepada Sekretaris Dewan Perwakilan Rakyat Daerah Provinsi Bengkulu diharapkan dapat memberikan tugas kepada pegawai sesuai dengan tupoksinya masing agar tidak terjadi kecemburuan sosial diantara sesame pegawai dan dapat memberikan honor pegawai bersifat adil sesuai dengan kinerja pegawai masing masing.

\section{DAFTAR PUSTAKA}

Anggara, Wisesa. (2011). “Integritas Moral dalam Konteks Pengambilan Keputusan Etis" Sekolah Bisnis dan Manajemen InstitutTeknologi Bandung. http://www.sbm.itb.ac.id.

Arikunto, Suharsimi. (2006). "Prosedur Penelitian Suatu Pendekatan Praktek”. Jakarta, Ed, VI Rineka Cipta.

Dewey, John. (1994). “The Moral Writings of John Dewey". New York: Amherst, Prometheus Books.

Djatmiko, Hayati, Yayat. (2008). "Perilaku Organisasi”. Bandung” Alfabeta.

Jones, T. M. (1991). "Keputusan Etis Pembuatan oleh Individu dalam Organisasi: Sebuah Model-Isu Kontingen. Ethical Decision Making by Individuals in Organizations: An Issue-Contingent Model”. Academy of Management Review 16 (2), 366-395. ttp://www.jstor.org/pss/258867.

Diakses Tanggal 13 Agustus 2014.

John de Santo dan Agus. (1995). "Tahaptahap Perkembangan Moral”. Yogyakarta: Kanisius.

Martono, Imam. (2009). “Faktor Keputusan Etis”. Jakarta: PT. Bumi Aksara.
Notoatmodjo, Soekidjo. (2002). “Metodologi Penelitian Kesehatan”. Yogyakarta: Rineka Cipta.

Ratna Indri Hapsari. (2010). “Pengaruh Kelompok Kerja Terhadap

Pengambilan Keputusan Etis Mahasiswa Akuntansi (Studi Eksperimen pada Mahasiswa Akuntansi Fakultas Ekonomi Universitas Diponegoro Semarang”.

Robbins, Stephen. (2006). "Perilaku Organisasi”. Jakarta: Edisi Lengkap, Indeks.

Sugiyono. (2008). "Metode Penelitian Kuantitatif dan Kualitatif dan $R \& D$ ”. Bandung: Alfabeta.

Suwandi, dkk. (2008). "Metode Penelitian Kualitatif”. Jakarta: EGC.

Suwarto. (2008). "Perilaku Organisasi, Buku Panduan Mahasiswa". Yogyakarta: Universitas Atma Yogyakarta.

Terry, George R. (2006). "Prinsip-Prinsip Manajemen”. Jakarta: PT. Bumi Aksara.

Utomo dan Sumanto. (2007). "Administrasi Publik Baru di Indonesia”. Yogyakarta: Pustaka Pelajar.

Universitas Bengkulu. (2013). "Pedoman Penulisan Tesis”. Bengkulu. 